\title{
Cloud Nuclei Spectra and Updrafts beneath Convective Cloud Bases in the High Plains
}

\author{
JoHN D. MARWITZ2 \\ Colorado State University, Fort Collins \\ AND August H. AUER, JR. \\ University of Wyoming, Laramie
}

(Manuscript received 9 October 1967, in revised form 9 December 1967)

\begin{abstract}
Air samples and updraft speeds were obtained simultaneously beneath the bases of convective clouds in northeastern Colorado and in South Dakota. Air samples were examined on the ground in a thermal diffusion nuclei chamber in the supersaturation range of $0.1-0.3 \%$ and the nuclei spectra determined. Using Twomey's technique, the maximum supersaturation was estimated, thereby estimating the number of cloud nuclei activated.

The updraft speeds were plotted against the concentration of activated cloud nuclei for varying storm intensities. The results indicate the dominate variable, in identifying storm intensity, is updraft strength, with 4-5 $\mathrm{m} \mathrm{sec}^{-1}$ being the cutoff point between thunderstorm and hailstorms. The data gave no clear indication that cloud nuclei concentrations played a significant role in identifying storm intensity. Since $N \propto V^{3 k /(2 k+4)}$, where $V$ is updraft strength, $N$ number of activated nuclei and the values of $k$ obtained from the analyzed air samples ranged from 0.4 to 2.9 , it was determined that in the case of High Plains convection the resulting relation between activated nuclei and updraft strength is $N \propto V^{0.25}$ to $V^{0.89}$.
\end{abstract}

\section{Introduction}

Twomey (1959) derived an equation relating the cloud nuclei spectrum and the updraft velocity to the probable range of maximum supersaturation in the cloud base, and hence, the number of droplets formed when condensation occurs on nuclei entering at cloud base. The accuracy of the maximum supersaturation is better than $30 \%$. The number of droplets, being proportional to the maximum supersaturation to power $k$, is given by the relation

$$
N=c S^{k}=c^{2 /(k+2)} \times\left[\frac{1.63 \times 10^{-3} V^{3} \Gamma\left(\frac{3}{2}+k / 2\right)}{k \Gamma\left(\frac{3}{2}\right) \Gamma(k / 2)}\right]^{k /(k+2)},
$$

where

$$
\begin{aligned}
& N=\text { the number of nuclei activated at the maximum } \\
& \text { supersaturation }{ }^{2} S\left({ }^{\circ} \mathrm{C}\right) \text {, } \\
& c=\text { the nuclei spectrum distribution constant, } \\
& k=\text { the slope of the nuclei-supersaturation dis- } \\
& \text { tribution, } \\
& V=\text { the updraft velocity }\left(\mathrm{cm} \mathrm{sec}^{-1}\right) \text { measured be- } \\
& \text { neath the cloud, and } \\
& \Gamma=\text { the gamma function. }
\end{aligned}
$$

\footnotetext{
${ }^{1}$ Present affiliation: University of Wyoming, Laramie.

${ }^{2}$ Elsewhere in the text and in Table 1 we have expressed $S$ in as a percentage since it is a more readily understood unit. The relation between $S\left({ }^{\circ} \mathrm{C}\right)$ and $S(\%)$ for $10 \mathrm{C}$ is $S\left({ }^{\circ} \mathrm{C}\right)=0.145 S(\%)$.
}

Squires and Twomey (1960) made observations of cloud nuclei spectra below cloud base and cloud droplets just above cloud base. They assumed updraft values of 1 and $10 \mathrm{~m} \mathrm{sec}^{-1}$ at cloud base. Their results indicated that cloud droplet concentrations were primarily a function of the nuclei spectra, with $N \propto V^{0.14}$ to $V^{0.25}$; hence, their assumed range of updrafts did not affect their results. Since these results are the only known experiments relating updrafts and cloud nuclei spectra to cloud droplet concentrations, one may thus conclude that Twomey's derived equation has not been thoroughly tested, especially for values of $k>1$, although it certainly must be correct in principle.

The strongest updraft velocities at cloud base occur along the leading edge of cumulus and cumulonimbus clouds (Ludlam, 1961 ; Newton, 1963, Browning, 1964; Auer and Sand, 1966). The Thunderstorm Project observed updraft speeds of $5-10 \mathrm{~m} \mathrm{sec}^{-1}$ with a maximum of $25 \mathrm{~m} \mathrm{sec}^{-1}$ at 25,000-ft MSL penetrations (Byers and Braham, 1949). Flight experience around cumulonimbi in Germany showed that the updraft speed averaged $4.5 \mathrm{~m} \mathrm{sec}^{-1}$ at cloud base (Ludlam, 1963). The Russian Bibilashvili (Battan, 1963) obtained values of 5-7 m sec-1 at the base of the cloud by tracking objects through thunderstorms with radar. Auer and Sand (1966) found average values of updrafts of $6 \mathrm{~m} \mathrm{sec}^{-1}$ beneath the cloud bases at the leading edge of heavily precipitating thunderstorms in northeast Colorado. 
TABLE 1. Data on updrafts, nuclei spectra, maximum supersaturation and number of activated cloud nuclei for classes of convection (TRWA $=$ hailstorms, $\mathrm{TRW}=$ thunderstorms, $\mathrm{Cu}=$ cumuli) in northeastern Colorado and in South Dakota.

\begin{tabular}{|c|c|c|c|c|c|c|c|}
\hline Date & $\begin{array}{l}\text { Time } \\
\text { (MDT) }\end{array}$ & $\begin{array}{c}\text { Updraft } \\
V\left(\mathrm{~m} \mathrm{sec}^{-1}\right)\end{array}$ & $\begin{array}{l}\text { Intercept } \\
\boldsymbol{c}\end{array}$ & $\underset{k}{\text { Slope }}$ & $\begin{array}{c}\text { Maximum } \\
\text { super- } \\
\text { saturation } \\
S_{\max }(\%)\end{array}$ & $\begin{array}{c}\text { Activated } \\
\text { nuclei } \\
N\left(\mathrm{~cm}^{-3}\right)\end{array}$ & Class \\
\hline \multicolumn{8}{|l|}{ NE Colorado } \\
\hline \multirow[t]{3}{*}{10 Jul. 65} & 1717 & 2.5 & 840 & 0.98 & 0.61 & 520 & TRW \\
\hline & 1737 & 11.0 & 1000 & 1.00 & 1.24 & 1200 & TRWA \\
\hline & 1808 & 6.0 & 940 & 1.30 & 1.37 & 1320 & TRWA \\
\hline 23 Jul. 65 & 1506 & 1.8 & 3500 & 1.00 & 0.61 & 320 & $\mathrm{Cu}$ \\
\hline 26)Jul. 65 & 1851 & 2.0 & 3650 & 0.87 & 0.56 & 425 & $\mathrm{Cu}$ \\
\hline 11'Aug. 65 & 1445 & 5.0 & 750 & 0.85 & 1.60 & 215 & TRW \\
\hline 30 Jul. 66 & 1745 . & 3.5 & 370 & 0.30 & 1.10 & 217 & TRW \\
\hline 1 Jul. 66 & 1724 & 4.5 & 5400 & 1.20 & 0.98 & 590 & TRWA \\
\hline $6 \mathrm{Jul} .66$ & 1919 & 4.5 & 4400 & 1.06 & 0.97 & 610 & TRWA \\
\hline 13 Jul. 66 & 1723 & 3.0 & 2000 & 0.80 & 0.83 & 380 & TRW \\
\hline 16 Jul. 66 & 1740 & 2.5 & 3700 & 1.06 & 0.75 & 355 & $\mathrm{Cu}$ \\
\hline 18 Jul. 66 & 1616 & 10.0 & 1100 & 0.51 & 1.61 & 535 & TRWA \\
\hline 19 Jùl. 66 & 1756 & 3.0 & 1100 & 0.78 & 1.00 & 250 & TRW \\
\hline $20 \mathrm{Jul} .66$ & 1915 & 3.0 & 800 & 0.40 & 0.32 & 240 & TRW \\
\hline 21 Jul. 66 & 1529 & 7.5 & 1300 & 0.86 & 1.60 & 395 & TRWA \\
\hline \multirow[t]{2}{*}{27 Jul. 66} & 1600 & 3.0 & 2500 & 0.75 & 0.73 & 475 & TRW \\
\hline & 1851 & 6.5 & 1500 & 0.40 & 0.84 & 625 & TRWA \\
\hline \multirow[t]{2}{*}{3 Aug. 66} & 1734 & 1.0 & 1900 & 0.58 & 0.41 & 390 & $\mathrm{Cu}$ \\
\hline & 1754 & 2.0 & 1200 & 0.58 & 0.71 & 350 & $\mathrm{Cu}$ \\
\hline 5 Aug. 66 & 1919 & 3.0 & 2550 & 0.78 & 0.75 & 465 & TRW \\
\hline 16.Aug. 66 & 1625 & 1.5 & 1700 & 0.60 & 0.55 & 380 & $\mathrm{Cu}$ \\
\hline \multirow[t]{2}{*}{18 Aug. 66} & 1736 & 0.5 & 1600 & 0.64 & 0.28 & 180 & $\mathrm{Cu}$ \\
\hline & 1758 & 3.0 & 4000 & 0.80 & 0.64 & 600 & $\mathrm{Cu}$ \\
\hline 19 Aug. 66 & 1505 & 1.0 & 2050 & 0.50 & 0.32 & 395 & $\mathrm{Cu}$ \\
\hline \multirow[t]{3}{*}{20 Aug. 66} & 1410 & 2.5 & 2600 & 0.92 & 0.76 & 355 & $\mathrm{Cu}$ \\
\hline & 1439 & 2.0 & 8800 & 1.20 & 0.59 & 465 & $\mathrm{Cu}$ \\
\hline & 1747 & 1.0 & 1200 & 0.54 & 0.41 & 265 & $\mathrm{Cu}$ \\
\hline 23 Aug. 66 & 1751 & 2.5 & 1120 & 0.65 & 0.82 & 280 & $\mathrm{Cu}$ \\
\hline \multirow[t]{2}{*}{30 Aug. 66} & 1722 & 0.5 & 960 & 1.00 & 0.50 & 71 & $\mathrm{Cu}$ \\
\hline & 1746 & 1.0 & 9800 & 1.70 & 0.61 & 175 & $\mathrm{Cu}$ \\
\hline \multirow[t]{3}{*}{1 Sept. 66} & 1038 & 1.0 & 1800 & 1.60 & 0.90 & 72 & $\mathrm{Cu}$ \\
\hline & 1100 & 2.0 & 860 & 1.00 & 1.14 & 143 & $\mathrm{Cu}$ \\
\hline & 1643 & 2.5 & 520 & 0.68 & 1.12 & 148 & $\mathrm{Cu}$ \\
\hline \multicolumn{8}{|l|}{ South Dakota } \\
\hline 14 Jul. 67 & 1540 & 4.5 & 6000 & 1.20 & 0.95 & 575 & TRWA \\
\hline 15 Jul. 67 & 1453 & 4.5 & 16,000 & 1.15 & 0.69 & 1130 & TRW \\
\hline \multirow[t]{3}{*}{24 Jul. 67} & 1656 & 2.0 & 1700 & 0.85 & 0.99 & 330 & TRW \\
\hline & 1723 & 3.5 & 8000 & 1.25 & 0.81 & 585 & TRW \\
\hline & 1918 & 5.0 & 200,000 & 2.35 & 0.74 & 1200 & TRWA \\
\hline \multirow[t]{2}{*}{25 Jul. 67} & 1520 & 5.0 & 13,000 & 1.45 & 0.97 & 795 & TRWA \\
\hline & 1544 & 7.5 & 330,000 & 2.87 & 0.69 & 3900 & TRWA \\
\hline $26 \mathrm{Jul} .67$ & 1628 & 3.0 & 2000 & 0.50 & 0.69 & 615 & TRWA \\
\hline \multirow[t]{2}{*}{$27 \mathrm{Jul} .67$} & 1450 & 7.5 & 14,000 & 1.80 & 1.31 & 675 & TRWA \\
\hline & 1547 & 3.5 & 40,000 & 1.85 & 0.69 & 710 & TRW \\
\hline \multirow[t]{2}{*}{$28 \mathrm{Jul} .67$} & 1411 & 2.5 & 14,000 & 1.78 & 0.81 & 325 & TRW \\
\hline & 1423 & 4.5 & 14,000 & 1.78 & 1.03 & 505 & TRW \\
\hline \multirow[t]{2}{*}{2 Aug. 67} & 1446 & 5.0 & 41,000 & 2.38 & 1.10 & 520 & TRWA \\
\hline & 1527 & 4.0 & 520 & 0.92 & 1.93 & 160 & TRWA \\
\hline
\end{tabular}

\section{Observations}

During the summers of 1965 and 1966 in northeast Colorado and 1967 in South Dakota, updraft measurements and air samples were gathered simultaneously beneath cloud bases of cumulus, towering cumulus, thundershowers and hailstorms. The clouds were selected based on the visual observations of the on-board meteorologist and without prior knowledge as to the presence of hail in the precipitation curtain. Those cases in which the convective cloud penetrated the cirrus cloud are not considered in this analysis. The convective activity was classified into the above cloud categories according to its most intense activity within $\pm 30 \mathrm{~min}$ of the observations. Using the technique outlined by Auer and Sand (1966), a mean updraft was measured by the aircraft during the period required to fill the air sample bag. The air samples were returned to the ground and promptly analyzed in a thermal diffusion nuclei 


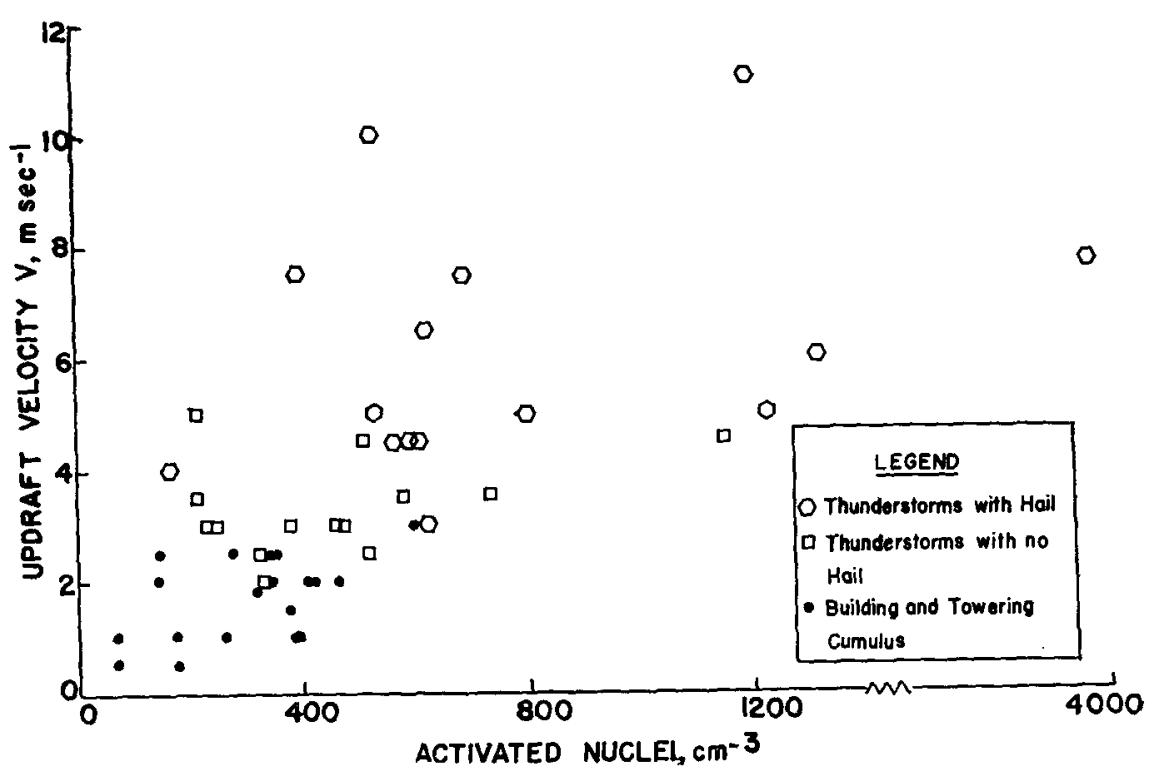

FIG. 1. The number of activated nuclei vs updraft velocities for cumulus clouds, thunderstorms and hailstorms in northeastern Colorado and in South Dakota.

chamber (Squires and Twomey, 1966) at supersaturations of less than $3 \%$. Nuclei concentrations were measured at three differing values of supersaturation in the thermal diffusion chamber. These three data points were used to determine the straight line plot of the nuclei-supersaturation relationships on $\log$-log paper, thereby yielding the values of the intercept constant $c$ and the slope $k$ for use in Twomey's equation. The number of activated nuclei was then evaluated by use of the Twomey equation. The observations were corrected for the diffusion of nuclei through the walls of the metalized mylar bags between the time the sample was taken until it was analyzed. The data are presented in Table 1.

\section{Results}

The results as shown in Fig. 1 indicate that the dominate variable in identifying storm intensity is updraft strength, with $4-5 \mathrm{~m} \mathrm{sec}^{-1}$ being the cutoff point between thunderstorms and hailstorms. The data gave no clear indication that cloud nuclei concentrations play a significant role in identifying storm intensity. Since $N \propto V^{3 k /(2 k+4)}$ and the values of $k$ obtained from the analyzed air samples ranged from 0.4 to 2.9 , it was determined that in the case of High Plains convection, the resulting relation between activated nuclei and updraft strength is $N \propto V^{0.25}$ to $V^{0.89}$. It is therefore suggested that in the case of High Plains convection, activated cloud nuclei concentrations have a greater dependence upon updraft strength than was found by Squires and Twomey (1960).
Acknowledgments. We wish to thank Dr. P. Squires for the use of the thermal diffusion cloud nuclei counter and for his advice during the process of this experiment. This research was supported by National Science Foundation Grants GP-2594 and GA-269 and the U. S. Department of the Interior, Bureau of Reclamation, Contract No. 14-06-D-5979 to South Dakota School of Mines, Institute of Atmospheric Sciences.

\section{REFERENCES}

Auer, A. H., Jr., and W. Sand, 1966: Updraft measurements beneath the base of cumulus and cumulonimbus clouds. $J$. Appl. Meleor., 5, 461-466.

Battan, L. J., 1963: A survey of recent cloud physics research in the Soviet Union. Bull. Amer. Meteor. Soc., 44, 757-758.

Browning, K. A., 1964: Airflow and precipitation trajectories within severe local storms which travel to the right of the winds. J. Atmos. Sci., 21, 634-638.

Byers, H. R., and R. R. Braham, 1949: The Thunderstorm. Washington, D.C., U.S. Government Printing Office, $287 \mathrm{pp}$.

Ludlam, F. H., 1961: The hailstorm. Weather, 16, 152-162. 1963: Severe local storms: A review. Meleor. Monogr., 5, No. 27, 1-30.

Newton, D. W., 1963: Dynamics of severe convective storms. Meleor. Monogr., 5, No. 27, 33-35.

Squires, P., and S. Twomey, 1960: The relation between cloud droplet spectra and the spectrum of cloud nuclei. Physics of Precipitalion, Gephys. Monogr. No. 5, Washington, D. C. Amer. Geophys. Union, 211-219.

_- and - -1966 : A comparison of cloud nucleus measurements over central North America and the Caribbean Sea. J. Atmos. Sci., 23, 401-404.

Twomey, S., 1959: The nuclei of natural cloud formation. Part II. The supersaturation in natural clouds and the variation of cloud droplet concentrations. Geofis. Pura A ppl., 43, 227-249. 